\title{
Islam Under Siege
}

\author{
Akbar Ahmed \\ Cambridge, UK: Polity Press, 2003. 213 pages.
}

Ahmed's Islam Under Siege is among the most popular books of the post9/11 period both in the West and in the Muslim world. The subtitle of the book poses as its summary: Living Dangerously in a Post-Honor World.

This multifaceted book addresses a wide audience, including those Americans in the Midwest who fearfully reflect upon the proverbial question "Why do they hate us?," Muslims who incessantly lament the acrimonious reality of Islam being associated with terrorism, and intellectuals who strive to discern the underlying factors of the crisis between Muslims and the West. Ahmed responds to the query "Could acts of violence be relegated merely to Muslim societies?" by adeptly elucidating the underlying factors of the Muslim world's crisis and the West's failure to understand Islam. In a historical context, he ponders the emergence of what he coins the "posthonor" world in which we live, and finally offers a road map to global peace. To alleviate extremist behavior and the rise of terrorism, he stresses the indispensability of - sine qua non - dialogue. He invites Muslims to acquire a self-critical retrospective insight so that they can apprehend their contribution to today's quagmire, and calls on non-Muslims to exercise more discernment in understanding the complexities in Muslims' lives.

The fulcrum of his argument is the notion of 'asabiyah and its convoluted form, dubbed "hyper-asabiyya," which he states creates an extremist demeanor in the Muslim world and ultimately results in violence. The term asabiyah refers to social cohesion, as described by the medieval social philosopher Ibn Khaldun, and is accrued in a society that is based on justice, compassion, and knowledge. The need to maintain it against the threat of any danger to the established social solidarity engenders a hyperbolic form of 'asab iyah, namely, "hyper-asabiyya." Given that 'asabiyah's main goal is to protect and preserve the society's "honor," the trepidation over losing honor or any loss of honor spurs a voracious desire to maintain or recover that honor. This inherent urge to preserve the "core" or regain what is already lost intensifies the emergence of "hyper-asabiyya." In other words, the breakdown of 'asabiyah (a lack of social cohesion) engenders "hyper-asabiyya," which is characterized by control and violence. Hence, ironically, while "hyper-asabiyya" arises because of the lack of 'asabiyah, the former is an exaggerated form of the latter. 
The most recent example of "hyper-asabiyya" is the 9/11 tragedy. Ahmed argues that the attacks' underlying impetus was the search for "lost" honor. According to Bin Laden, Muslims have long been humiliated across the globe due to their lack of confidence and their suppressive, corrupt reigning regimes that act in alliance with the United States. In order to reclaim this lost Muslim honor, Bin Laden aimed at the honor of the United States, the one country from his vantage point that was, in a way, responsible for the subjugation of Muslims. As a result, he came to be considered a hero by many Muslims. On the other hand, Bush was dubbed a "man of honor" for responding by attacking Afghanistan to reclaim the damaged honor of the American people. Hence, ironically, honor brought both Bin Laden and Bush to the same platform. The attacks became a defining moment for the outset of the "post-honor" world.

Ahmed discusses globalization's inextricable contribution to "hyperasabiyya." Globalization plays a paramount role in creating critical masses of socially, politically, and economically frustrated Muslims. He stresses the distinction between the Muslims' stance on the notion of "globalization" and the current trajectory of globalization. It is not globalization per se to which Muslims, as members of the developing world (after all, the author points out, Muslims promoted a relative globalization ideology during their civilizations), object, but to the invariable "favoritism" promoted by the West, in particular the United States, to serve its own interests. This creates discomfort, sentiments of humiliation, and the urge to reclaim justice and revenge, all of which ineluctably add to the factors that engender "hyper-asabiyya." The author also pays attention to the apprehension of "too much change at too great a pace" vis-à-vis globalization among Muslim societies.

Ahmed's thesis on leadership is well-received by devout Muslims: The closer the political leadership is to the Islamic ideal, the lesser the tension in society. Ahmed calls for an "Islamic ideal" based on Qur' anic principles and the Prophet's Sunnah. He moves through the four categories of governance, namely, clerical, monarchy-militarist, socialistcommunist, and democracy, and infers that democracy is the most viable, for it is the means to reach the "Islamic ideal."

He refers to the plight of Muslim women today as "catastrophic." While women were active members of Islamic society during the revelation's early years, in many parts of the Muslim world their role gradually deteriorated and came to be defined more by culture than by religion. Islamic history is replete with examples of women professionals, warriors, 
thinkers, and intellectuals. While ruminating over the reasons behind the "collapse" of Muslim women, Ahmed's discussion of colonization's impact on Muslim lands rivets the reader's attention. Ahmed proclaims that nineteenth- and twentieth-century colonization played a significant role in the emergence of "hyper-asabiyya" factors, and, in return, engendered a "loss of confidence" among Muslims. This loss, in turn, triggered the need to "protect" women via control and restraint.

In the last chapter, Ahmed turns to possible alternatives that Muslims can use to move forward toward a road map. His empirical comparison of the ideal of inclusion and the exclusionist approach patently depicts that Muslims must pursue the ideal of inclusion, namely, the path of dialogue and tolerance.

Ahmed asserts that the Muslim world has to establish the aforementioned "ideal of Islam." To a certain extent, he alludes to pragmatic means to achieve this goal. Nonetheless, there are still questions to be addressed, one of which is how to contend with western governments, some of which actually bolster the current instability in the Muslim world and thus quench the democratization process. His road map for western governments - to promote justice via promoting "real" democracy - is valuable. Nevertheless, it is based on a "moral" compass, which means that its applicability becomes problematic for those who may lack such a compass.

Merve Kavakci

Elliot School of International Affairs

George Washington University

Washington, DC 